\title{
NEPHRITIS IN INFANGY
}

BY

\section{J. BASIL RENNIE, M.B., Ch.B., F.R.F.P.S.*}

(From the Department of Paediatrics, Glasgow University, and the Biochemical Laboratory, Royal Hospital for Sick Children, Glasgow.)

Although the subject of nephritis has been studied from many aspects, comparatively few reports are extant on the manifestations of the disease as it occurs in infancy. In this communication are discussed the cases of nephritis, ten in number, occurring in infants under eighteen months admitted to the Royal Hospital for Sick Children, Glasgow, during the past three years. The cases described constitute $0 \cdot 4$ per cent. of total admissions to the medical wards of the same age period and 5.5 per cent. of all cases of acute nephritis under thirteen years.

Case records.

In addition to the clinical and biochemical findings short notes of the post-mortem manifestations in the fatal cases are given.

Gase 1.-J. McD., admitted 18.2.33, was a boy aged nine months, a fourth child, with a good family history. Pregnancy and labour had been normal. He was breast-fed and' throve well till a week before admission when oedema, first noticed in the face, appeared. On admission he was found to be a fairly well-nourished child, afebrile, with marked anasarca and ascites present. The Wassermann reaction was negative. The urine contained $20 \mathrm{gm}$. per litre of albumin, with a positive guaiacum reaction and numerous casts and red blood corpuscles.

The biochemistry of this case is of particular interest because of the fact that nine observations were made on the serum proteins during the course of the disease until recovery was established. As can be seen from the following figures, a close relation exists between the serum oncotic pressure level and the extent of the oedema.

A high protein diet containing $68 \mathrm{gm}$. protein per day or about $8 \mathrm{gm}$. per $\mathrm{kgm}$. body weight was given for four weeks. From the time of the first observation calculated serum oncotic pressure rose steadily. When it reached $20 \cdot 2 \mathrm{~mm}$. $\mathrm{Hg}$. no cedema was observed (see fig. 1). At that point the albumin in the urine had fallen to $1 \mathrm{gm}$. per litre.

\begin{tabular}{|c|c|c|c|c|c|c|c|c|c|}
\hline Date & $\begin{array}{c}\text { Total } \\
\text { prot. } \mathrm{gm} .\end{array}$ & $\begin{array}{l}\text { Alti. } \\
\text { gm. }\end{array}$ & $\begin{array}{l}\text { Glob. } \\
\text { gm. }\end{array}$ & $\begin{array}{l}\text { N.P.X. } \\
\text { mgm. }\end{array}$ & $\begin{array}{l}\text { Onc. } \\
\text { press mim.; } \\
\text { Hg. (cale) }\end{array}$ & $\begin{array}{l}\text { Serum } \\
\text { ca. } \\
\text { mgm. }\end{array}$ & $\begin{array}{l}\text { Serum } \\
\text { Phos. } \\
\text { mgm. }\end{array}$ & $\begin{array}{l}\text { Wt. } \\
\text { (Kg.) }\end{array}$ & Remarks. \\
\hline & \multicolumn{4}{|c|}{ All percentage figures. } & \multicolumn{4}{|c|}{ Perrent agre figures. } & \multirow[b]{2}{*}{ Oedema + + } \\
\hline .2 .33 & $3 \cdot 67$ & $1 \cdot 80$ & $1 \cdot 87$ & $28 \cdot 0$ & $12 \cdot 5$ & 7.8 & $4 \cdot 8$ & 105 & \\
\hline 7.2.33 & $4 \cdot 24$ & $1 \cdot 80$ & $2 \cdot 44$ & $27 \cdot 0$ & $13 \cdot 3$ & $8 \cdot 2$ & $4 \cdot 3$ & $10 \%$ & \\
\hline 13.3 .33 & $3 \cdot 02$ & $2 \cdot 38$ & $1: 54$ & $27 \cdot 2$ & $15 \cdot 2$ & $5: 5$ & $4 \cdot 9$ & $10 \cdot 7$ & Orchitis, fever \\
\hline 2.3.33 & $4 \cdot 34$ & $2 \cdot 19$ & $2 \cdot 15$ & $20 \cdot 0$ & $15 \cdot 0$ & $6 \cdot 3$ & $4 \cdot 7$ & $10 \cdot 3$ & \\
\hline 4.3 .33 & $6 \cdot 2 \cdot 2$ & $2 \cdot 16$ & $4 \cdot 05$ & $25 \cdot 3$ & $17: 5$ & $11 \cdot 0$ & $4 \cdot 9$ & $9 \cdot \overline{5}$ & Oedema less \\
\hline 29.3 .33 & 678 & $2 \cdot 24$ & $4 \cdot 54$ & $25 \cdot 0$ & $18 \cdot 7$ & $9 \cdot 0$ & $5 \cdot 2$ & $8 \cdot 1$ & $\begin{array}{l}\text { Testicular } \\
\text { abscesses }\end{array}$ \\
\hline 10.4 .33 & $5 \cdot 83$ & $2 \cdot 93$ & $2 \cdot 89$ & $41 \cdot 6$ & $20 \cdot 2$ & $8 \cdot 6$ & - & $8 \cdot 2$ & No oedema \\
\hline $\begin{array}{l}13.4 .33 \\
25.9 .33\end{array}$ & $\begin{array}{l}5 \cdot 86 \\
6 \cdot 99\end{array}$ & $\begin{array}{l}3 \cdot 54 \\
4 \cdot 18\end{array}$ & $\begin{array}{l}2 \cdot 32 \\
0.81\end{array}$ & $37 \cdot 0$ & $22 \cdot 7$ & - & - . & - & ,' \\
\hline .9 .33 & 6.99 & $4 \cdot 18$ & $2 \cdot 81$ & $27 \cdot 0$ & $26 \cdot 9$ & - & $4 \cdot 8$ & 一 & Ürine clear. \\
\hline
\end{tabular}

\footnotetext{
* The work was carried out during the tenure of a Carnegie Research Scholarship.
} 
At first glance cure in this case may seem to be connected with the administration of a diet high in protein for which some observers claim good results in the treatment of lipoid nephrosis and the nephrotic syndrome of glomerulo-nephritis. It is, however, well known that spontaneous rise of serum proteins may occur, and in this case after four weeks of high protein feeding the diet was changed to half milk, providing only $2.0 \mathrm{gm}$. of protein per kgm. body weight, and this did not interfere with the rise of serum proteins (see fig. 1). It is also known that infections may cause a rise in

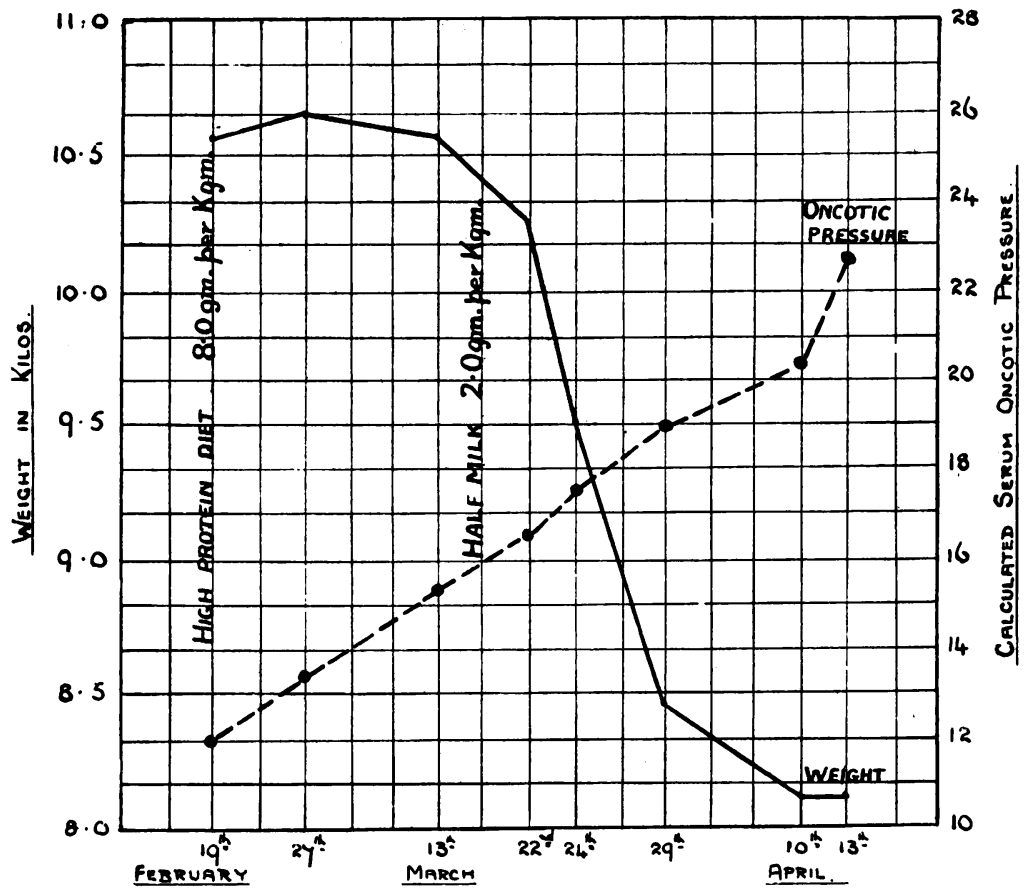

FIG. 1. Relation of oncotic pressure of the serum to oedema.

serum globulin (Bruckman et alii $\left.{ }^{1}\right)$. In this case the development of suppurative orchitis probably accounted for the high globulin found on 24.3.33 and 29.3.33. If the theory of Epstein $^{2}$ and others that the nephrotic syndrome is a metabolic upset be correct and that the normal production of serum proteins is interfered with, then it is possible that an infection may act as a stimulus to the production of serum proteins, but the possibility of rise in serum albumin being spontaneous must not be lost sight of as a steady return to normal occurred from the first blood observation. Nonprotein nitrogen was normal save on the occasion when it reached $41.6 \mathrm{mgm}$. per cent. This slight rise above the normal level was possibly associated with the suppurative process. Serum calcium on the whole tended to be low when serum protein was low though this was not invariably the case. Serum phosphorus was normal. That the reduction of serum protein was not due to dilution of the blood may be inferred (a) from the observation 
that the protein fractions were not reduced equally and (b) from the fact that the haematocrit readings, the red cell count and the haemoglobin level were normal. No red blood corpuscles were seen in the urine after the eighth day in hospital. Seven months after the onset of the illness the child appeared to be perfectly well, at which time the urine contained no abnormal constituents and serum proteins were normal.

Case 2.-I. G., a female, aged one year and three months, was an only child of healthy parents, breast fed till nine months and throve well. Six weeks before admission both ears discharged pus for four weeks and the child became pale, listless and vomited occasionally. Four weeks before admission a purulent nasal discharge began. There was no history of oedema. Admitted to hospital on 7.9.33, she was a pale child, fairly well nourished, with a puffy face and slight pitting over the tibiae. Nothing abnormal was detected in the heart, lungs, nervous system or abdomen. Ophthalmoscopic examination was negative. The urine contained 3.5 gm. of albumin per litre, red blood cells were exceedingly scanty and some casts were seen. Culture of the urine was negative. Two days later the body weight had remained stationary but slight fever had developed, the temperature reaching $100^{\circ}$ F., with the reappearance of a purulent nasal discharge. The Wassermann reaction was negative. The blood pressure in $\mathrm{mm}$. Hg. was 98 systolic and 56 diastolic. Puffiness of the face was still present.

18.9.33. Oedema was absent. Passage of loose green stools commenced on 17.9.33. with frequent vomiting.

21.9.33. The child was removed from hospital against advice. $1.2 \mathrm{~kg}$. body weight had been lost during past four days. Enteritis was still present, but there was no oedema.

14.10.33. The child was seen as an outpatient. Since discharge the enteritis had continued and the baby appeared to be very dehydrated and ill. $\mathbf{A}$ catheter specimen of urine showed no albumin, casts or blood. The mother refused to leave the child in hospital and the child died at home five days later. (No examination of the blood was made on 14.10.33).

The following are the blood chemistry findings:-

\begin{tabular}{|c|c|c|c|c|c|c|c|c|}
\hline \multirow[t]{2}{*}{ Date } & & $\begin{array}{c}\text { Total } \\
\text { prot. gm. }\end{array}$ & & Gilob. gm. & \multirow[t]{2}{*}{$\begin{array}{c}\text { Onc. press. } \\
\text { mm. Hg. } \\
\text { (calc.) }\end{array}$} & \multirow{2}{*}{$\begin{array}{l}\text { N.P.N. } \\
\text { mgm. } \\
\text { per cent. }\end{array}$} & \multirow[t]{2}{*}{ Oedema } & \multirow[t]{2}{*}{ Remarks } \\
\hline & & Perc & ntage $f$ & ures & & & & \\
\hline & $\ldots$ & $3 \cdot 80$ & $2 \cdot 40$ & $1 \cdot 40$ & 15.2 & $29 \cdot 2$ & \pm & \\
\hline 9.33 & $\ldots$ & $5 \cdot 21$ & $2 \cdot 13$ & $3 \cdot 08$ & $16 \cdot 0$ & $28 \cdot 0$ & - & Enteritis \\
\hline
\end{tabular}

It can be seen that rise in serum oncotic pressure was but slight. Even at as low a level as $16.0 \mathrm{~mm}$. $\mathrm{Hg}$. oedema was absent. It is probable that the dehydrating influence of the enteritis played a large part in the disappearance of the oedema. Possibly the rise in serum globulin was associated with the presence of an infection or, less probably, may have indicated spontaneous regeneration of the serum proteins.

Case 3.-A. H., was a boy six months old. The first pregnancy ended in a miscarriage, but otherwise the family history was good and the patient's three brothers and sisters were alive and well. Breast fed for one month he afterwards received Nestlés milk. He throve until at five months old he contracted chicken-pox which was followed a week later by enteritis. Two weeks later generalized oedema was observed and he was admitted to hospital on 16.6.31. 
He was a well-nourished infant with oedema involving face, sacrum, scrotum, thighs and legs. Ascites was also present. In the lungs some rhonchi were heard. In the heart and nervous system no abnormality was detected. The urine contained $11 \mathrm{gm}$. of albumin per litre and the guaiacum reaction was positive. Numerous red blood corpuscles and casts were present. Urine culture was negative; the stools were loose and green. An ophthalmoscopic examination was negative.

16.6.31. Blood pressure was $85 / 55 \mathrm{~mm}$. $\mathrm{Hg}$.

BloOD chenISTRY.-Total protein $4.09 \mathrm{gm}$. per cent.; albumin $1.63 \mathrm{gm}$. per cent.; globulin $2 \cdot 46 \mathrm{gm}$. per cent.; calculated serum oncotic pressure $12 \cdot 4 \mathrm{~mm}$. Hg.; N.P.N. $27.5 \mathrm{mgm}$. per cent.; and serum Ca. 5.4 mgm. per cent.

From the day of admission enteritis continued and the child steadily lost weight (2.3 kgm.), became dehydrated and died on 24.6.31.

A post-mortem examination showed enteritis and hypostatic congestion of lungs. On histological investigation a mixed type of nephritis was found, the changes being chiefly in the tubules. No evidence of congenital syphilis was found.

Case 4.-S. C., a male aged one year and four months, was the tenth child of healthy parents. Their second child was still-born and the rest of the family history was not relevant. He was breast fed and throve till eleven months old when he developed ? encephalitis and was in the Royal Hospital for Sick Children for six weeks. At that time the Wassermann reaction of blood and cerebrospinal fluid was found to be negative. The urine contained no abnormal constituents. A week before his second admission generalized oedema occurred but no abnormality of the urine was observed by the mother. Re-admitted to the Royal Hospital for Sick Children on 30.8.32, aged one year and four months, he had oedema of face, sacrum and legs. Ascites was also present. The urine contained much albumin, 14. $\mathrm{gm}$. per litre and the guaiacum reaction was positive. Numerous red blood cells and casts were present. The urine culture was negative.

BlOOD ChEMISTRY, 31.8.32.-Total protein $4 \cdot 54 \mathrm{gm}$. per cent.; N.P.N. 24.1 mgm. per cent.; and serum Ca. 6.4 mgm. per cent.

During a stay in hospital of 22 weeks oedema was present in varying degree for 16 weeks. It diminished during administration of ammonium chloride and also during a febrile period due to otitis media but also at other times for no apparent reason and the reduction of oedema could not be related to any form of diet or therapeutic measure. Haematuria persisted for $\mathbf{1 5}$ weeks. Albuminuria was present throughout and the child was dismissed as a chicken-pox contact while the urine still contained much albumin. Blood was absent.

6.6.33. Child reported in out-patient department much improved. A cough had been present for two weeks. No oedema had been observed: temperature $100^{\circ} \mathrm{F}$. Numerous rhonchi were audible in both lungs. Urine contained a trace of albumin but no casts nor red cells were seen. The blood chemistry findings were :-total protein 9.95 $\mathrm{gm}$. per cent.; albumin 5.83 gm. per cent.; globulin $4 \cdot 12 \mathrm{gm}$. per cent.; calculated serum oncotic pressure $37.8 \mathrm{~mm}$. Hg.; and N.P.N. $25 \mathrm{mgm}$. per cent.

6.4.34. Urine normal.

While in this case serum albumin and serum globulin were not estimated separately during the stay in hospital it can be seen that there was a rise of serum proteins to above normal level. This is due to increase in both albumin and globulin, the high globulin being probably explained by the presence of the respiratory infection which later was found to be whooping cough.

Case 5.-C. G., a male, was aged four months. Family history was good. He was breast fed and throve till two weeks before admission when puffiness of the face was noted. Admitted to hospital on 4.2.33, he had oedema of face, sacrum and legs 
and some ascites. The heart, lungs and nervous system showed no abnormality. The urine contained much albumin but casts were not numerous and red cells were very scanty. Urine culture was negative.

Blood Chemistry, 6.2.33.-Total protein $4.84 \mathrm{gm}$. per cent.; albumin 1.60 gm. per cent.; globulin 3.24 gm. per cent.; calculated serum oncotic pressure $13.3 \mathrm{~mm}$. Hg.; N.P.N. $50 \mathrm{mgm}$. per cent.; serum Ca $5.8 \mathrm{mgm}$. per cent.; serum phosphorus 7.0 mgm. per cent.

12.2.33. Numerous: loose stools were passed during the stay in hospital and on 14.2.33 child became comatose and began to have convulsions. Lumbar puncture was performed and the cerebrospinal fluid was found to be normal. Death occurred on the same date.

Post-mortem examination showed marked oedema of the brain. No evidence of congenital syphilis was found. Areas of intense congestion were present in the small bowel. Both kidneys were swollen and the capsule was slightly adherent. Histologically subacute nephritis was present with well-marked tubular involvement and extensive proliferation of the interstitial tissue with foci of round-cell infiltration.

There are two possibilities. (a) The convulsions may have been terminal and due to an intense toxaemia arising from bowel infection. (b) The convulsions may have been symptomatic of true uraemia and it is somewhat significant that the only instance of convulsions in this series occurred in the child whose kidneys showed interstitial changes. This together with the increased concentration of non-protein nitrogen and inorganic phosphorus in the blood lend some support to this view.

Case 6.-G. A., a boy, aged one year and four months, was admitted on 7.9.33. He was a healthy infant, breast fed for one month, then receiving cow's milk till one year old and subsequently a mixed diet. He throve till four weeks before admission when he began to refuse food and two weeks before admission oedema of the face was noted. On admission he was found to be a small child with moderate degree of oedema of the legs, face and sacral region. The blood pressure was $100 \mathrm{~mm}$. Hg. systolic and 70 diastolic. Ophthalmoscopic examination was negative. The urine contained albumin up to $12 \mathrm{gm}$. per litre but red cells were very scanty although casts were numerous. The Wassermann reaction was negative. Urine culture was negative. As previous experience had shown that fatal enteritis was prone to supervene in such cases this child was dismissed from hospital although the urine still contained albumin, $4 \mathrm{gm}$. per litre, and there was still slight oedema. On dismissal the child attended the out-patient department and was observed to weather an attack of diarrhoea shortly afterwards. Two weeks following dismissal the urine was found to be quite free of albumin. The oedema had disappeared entirely during the attack of diarrhoea and never returned. Since that time the child has been perfectly well.

\section{BLOOD CHEMistry.}

\begin{tabular}{|c|c|c|c|c|c|c|c|c|c|}
\hline Date & $\begin{array}{l}\text { Total } \\
\text { prot. } \\
\text { gm. }\end{array}$ & $\begin{array}{l}\text { Alb. } \\
\text { gm. } \\
\text { rcenta }\end{array}$ & $\begin{array}{l}\text { Slob. } \\
\text { gm. }\end{array}$ & $\begin{array}{l}\text { N.P.N. } \\
\text { mgm. }\end{array}$ & $\begin{array}{c}\text { Onc. } \\
\text { press. } \\
\text { mm. } \\
\text { Hg. } \\
\text { (calc.) }\end{array}$ & $\begin{array}{c}\text { Serum } \\
\text { ca. } \\
\text { mgm. } \\
\text { Perc } \\
\text { fig }\end{array}$ & $\begin{array}{l}\text { Serum } \\
\text { phos. } \\
\text { mgm. } \\
\text { ntage } \\
\text { res }\end{array}$ & $\begin{array}{c}\text { Wt. } \\
\text { (kgm.) }\end{array}$ & Remarks \\
\hline 8.9 .32 & $\overparen{4 \cdot 51}$ & $2 \cdot 92$ & 1.59 & 28.5 & $18 \cdot 3$ & $9 \cdot 2$ & 5.5 & $8 \cdot 4$ & Oєdema + \\
\hline 14.9 .32 & $5 \cdot 63$ & $2 \cdot 25$ & $3 \cdot 38$ & $35 \cdot 7$ & $17 \cdot 1$ & $7 \cdot 3$ & $4 \cdot 8$ & $7 \cdot 7$ & Oedema \pm \\
\hline $15,5.33$ & $7 \cdot 31$ & $5 \cdot 32$ & 1.99 & $31 \cdot 2$ & $31 \cdot 8$ & - & - & - & $\begin{array}{l}\text { Uedema gone; } \\
\text { urine clear } \\
\text { C }\end{array}$ \\
\hline
\end{tabular}


The diminution in oedema at the time of the second observation (14.9.32) while serum oncotic pressure had fallen slightly may be explained by the fact that while in hospital the child was receiving a diet of milk, containing much less salt than is found in mixed diet. The rise in globulin on 14.9.33 may have been indicative of regeneration of the serum proteins but more probably was a reaction to the bowel infection.

Case 7.-J. N., a male aged one year, was an only child of healthy parents who was breast fed and throve till two weeks before admission when oedema was observed. Admitted to hospital on 26.10.31, the patient was a big child with marked oedema involving face, chest wall, lumbar region and legs. Ascites also was present. The heart, lungs and nervous system showed no abnormality. Ophthalmoscopic examination was negative. Blood pressure was $98 \mathrm{~mm}$. Hg. systolic and 60 diastolic. The urine contained much albumin and the guaiacum test was positive. Casts and red cells were numerous. Urine culture was negative.

Blood chemistry. Total protein $4.23 \mathrm{gm}$. per cent.; albumin 1.96 gm. per cent.; globulin $2 \cdot 27$ gm. per cent.; calculated serum oncotic pressure $13.9 \mathrm{~mm}$. Hg.; N.P.N. $36 \cdot 3 \mathrm{mgm}$. per cent.; serum calcium $9 \cdot 8 \mathrm{mgm}$. per cent.; serum phosphorus $5 \cdot 4 \mathrm{mgm}$. per cent.

On the day after admission severe enteritis developed, much oedema was lost but some was still present along with much albumin and blood in the urine when the child died six days after admission. Permission for an autopsy was refused. This child died of enteritis complicating nephritis.

Case 8.--E. K., was a female aged seven months, whose family history was good. She was fed on whole cow's milk and progressed well till three weeks before admission when swelling of the face was noticed and a week before admission the abdomen became prominent. Admitted to Royal Hospital for Sick Children on 23.6.31, she was a small child with moderate oedema of feet, slight ascites and puffiness of the face. The urine contained much albumin-11 gm. per litre-scanty casts and red cells. Culture of the urine was negative.

27.6.31. The child died, stools being frequent and vomiting persistent for the preceding four days. No oedema was then apparent, $1.70 \mathrm{kgm}$. having been lost.

Post-mortem examination. A few patches of bronchopneumonic consolidation were present in the lungs. No evidence of congenital syphilis was found. Histological report: early acute glomerulo-nephritis with marked cloudy swelling of the tubular epithelium present.

Case 9.-G. R., a male aged eight months, with a good family history, was breast fed and throve till four weeks before admission when generalized oedema was observed. The urine at that time was reported to be dark in colour. Admitted to hospital on 17.10.31, he had a marked degree of oedema involving face, legs and lumbar region. Slight ascites was present. Examination of heart, lungs and nervous system showed no abnormality. The urine contained albumin, $15 \mathrm{gm}$. per litre, the guaiacum reaction was negative and red cells were scanty. Casts were fairly numerous.

BloOd Chemistry, 21.10.31. Total protein $6.78 \mathrm{gm}$. per cent.; albumin $2.66 \mathrm{gm}$. per cent.; globulin $4 \cdot 12 \mathrm{gm}$. per cent.; calculated serum oncotic pressure $20 \cdot 4 \mathrm{~mm}$. Hg.; N.P.N. 29.1 mgm. per cent.; and serum Ca. $9 \cdot 2 \mathrm{mgm}$. per cent.

22.10.31. Oedema much less. Fever, present since day after admission, increased steadily and signs of pneumonia were noted on 23.10.31. The stools became loose and the child lost oedema rapidly and died nine days after admission.

Post-morten examination. Both lungs showed bronchopneumonia. The brain was oedematous. No evidence of syphilis was detected. Histological report of kidneys: early acute glomerulo-nephritis was present with well-marked swelling of the convoluted tubules. 
This child died of pneumonia complicating acute nephritis. From the high serum oncotic pressure level it is likely that blood examination was carried out after diuresis had begun. This is borne out by the rapid loss of oedema which was observed on the following day. Presumably the pneumonia was responsible for the increase in globulin which compensated for the deficiency in albumin and thus allowed serum oncotic pressure to reach a level compatible with diuresis.

Case 10.-S. L., was a boy aged one year and one month. The first and third pregnancies ended in stillbirths. He was breast-fed and throve till a fortnight before admission when oedema developed and the urine was observed to be dark in colour. Admitted to hospital on 5.4.34 with generalized oedema and ascites. No abnormality was detected in heart or lungs. The urine contained albumin-20 gm. per litre-and much blood. Casts were numerous. The Wassermann reaction was negative. The child was afebrile till the development of a cellulitis of the abdominal wall on 29.4.34, which proved fatal on 1.5.34.

BLOOD CHEMISTRY.

\begin{tabular}{|c|c|c|c|c|c|c|c|c|}
\hline \multirow[t]{2}{*}{ Date. } & $\begin{array}{c}\text { Total prot. } \\
\text { gm. }\end{array}$ & $\begin{array}{l}\text { Alb. } \\
\text { gm. }\end{array}$ & $\begin{array}{l}\text { Glob. } \\
\text { gm. }\end{array}$ & $\begin{array}{l}\text { Onc. } \\
\text { press. mm. } \\
\text { Hg. (calc.) }\end{array}$ & $\begin{array}{l}\text { N.P.N. } \\
\text { mgm. }\end{array}$ & $\begin{array}{c}\text { Serum } \\
\text { Ca } \\
\text { mgm. }\end{array}$ & $\begin{array}{l}\text { Serum } \\
\text { Phos. } \\
\text { mgm. }\end{array}$ & $\begin{array}{r}\text { Weight } \\
\text { (kgm.) }\end{array}$ \\
\hline & \multicolumn{3}{|c|}{ Percentage figures. } & \multicolumn{5}{|c|}{ Percentage figures. } \\
\hline 6.4 .34 & $4 \cdot 32$ & $2 \cdot 46$ & $1 \cdot 86$ & $16 \cdot 1$ & $65 \div 2$ & $8 \cdot 1$ & $6 \cdot 6$ & 10.5 \\
\hline .4 .34 & $4 \cdot 91$ & $2 \cdot 52$ & $2 \cdot 39$ & $17 \cdot 2$ & $39 \cdot 9$ & $\dot{-}$ & - & $10 \cdot 3$ \\
\hline 1.5 .34 & $4 \cdot 27$ & $1 \cdot 39$ & $2 \cdot 88$ & $11 \cdot 7$ & $29 \cdot 1$ & $4 \cdot 7$ & - & $10 \cdot 8$ \\
\hline
\end{tabular}

In this case some nitrogen retention was present on the first blood examination but not subsequently. Permission for autopsy was refused.

Previous work.

Before the clinical features and biochemical findings of the present series are discussed it is proposed to summarize the published reports of previous investigations. As has already been said the literature on nephritis in the period of infancy is scanty.

Henoch $^{3}$ recognized the existence of both acute and chronic nephritis in infants and noted that oedema was its most prominent manifestation. In the edition of his text-book published in 1899, Holt ${ }^{4}$ described the symptomatology of what he termed acute exudative nephritis in children under two years but included as synonymous titles acute desquamative nephritis, acute parenchymatous nephritis and acute septic interstitial nephritis. In the condition he described, the onset was abrupt with high fever and vomiting, while oedema was exceptional, being present in only six out of twenty-three cases and then slight in degree and only towards the termination of the disease. Dyspnoea was observed frequently but was ascribed to anaemia. Muscular twitchings were common and convulsions occurred in three cases. Albuminuria, frequently absent early in the attack, was rarely gross. Although casts were not usually numerous, many pus and endothelial cells were seen together with red blood corpuscles in moderate numbers. The mortality was high. At autopsy the kidneys presented a mottled appearance due to the aggregation of pus cells and even abscesses were often found. It seems evident that Holt was describing pyelonephritis, and in later editions of his book he did not include these symptoms in his descriptions of acute parenchymatous nephritis. 
Spence $^{5}$, also states that oedema is rare and emphasizes the presence of marked dyspnoea which he attributes to nephritic acidosis. He considers azotaemia an important diagnostic feature, the level of the non-protein nitrogen in the blood occasionally being as high as 100-150 mgm. per cent. He states that the prognosis is grave. Such a description might include any condition associated with severe toxaemia and dehydration, since albuminuria, acidosis and azotaemia are not uncommon features in these conditions. But against this objection Spence ${ }^{5}$ mentions the presence of casts and blood cells in the urine.

A series of cases reported by Boyd ${ }^{6}$ were hydraemic in type and resulted in almost 100 per cent. cure unless fatal secondary infection occurred. Still ${ }^{7}$ mentions the occurrence of uephritis with oedema in an infant five days old. In forty-nine cases of acute nephritis in children, Paterson and $W_{y l l i e}{ }^{8}$ record seven of parenchymatous type occurring between the age of one and three years. Of the series reported by Lyttle and Rosenberg ${ }^{9}$, of seventy-four cases of acute glomerular nephritis, seventeen acute diffuse and eight acute tubular, three, one, and two cases respectively occurred under two years. Levy ${ }^{10}$ found seventeen cases of nephritis in infants under a year in 1,000 admissions to hospital over a period of ten years. Of these seventeen, fourteen died, giving a mortality rate of 82 per cent. as against one of 19 per cent. for total admissions. These cases he divides into three groups of different aetiology: (a) Nephritis complicating erythrodermia desquamativa-five cases. All these patients died, four of the primary disease and one of sepsis. (b) Nephritis occurring in the course of congenital syphilis-six cases. In three there was albuminuria with casts and scanty red blood corpuscles in the urine and oedema. A fourth had more marked haematuria and slight oedema. The remaining two cases showed signs similar to the first three, but Levy considers that they developed nephritis as a result of treatment for syphilis. All died. (c) Nephritis in the course of an acute infection or nephritis sui generis-six cases. Of these, three followed bronchopneumonia, enteritis or erysipelas. They showed marked albuminuria and oedema and are classed as degenerative in type. All the patients died. Three other cases of nephritis arose spontaneously and were considered to be examples of acute glomerular nephritis. Oedema and albuminuria were less marked and haematuria was more prominent than in the cases of the degenerative type.

Levy concludes that nephritis in infancy is a rare disease. On the other hand, Brown ${ }^{11}$, in Toronto, found fourteen cases under eighteen months in 109 cases of nephritis in children over a period of five years. Gray ${ }^{12}$ describes a case of nephritis in an infant aged eight and a half months of five weeks duration during which oedema was constantly present. The albumin in the urine measured 10-19 gm. per litre during the last twelve days of life and enough blood was usually present to give a positive reaction to the guaiacum test. Casts were numerous. The Wassermann reaction was negative. At autopsy tubular degeneration was present and doubtful glomerular changes. This case is classified by Gray as nephrotic nephritis.

Osman $^{13}$ discusses the effect of large doses of alkali on a child aged eleven months with oedema which appeared fourteen days before admission to hospital. Albumin exceeded $6 \mathrm{gm}$. per litre. Casts were numerous but no blood was seen. For seventeen days potassium citrate and sodium bicarbonate, 120 grains of each, were given daily. Oedema then disappeared but possibly the gastro-enteritis which developed played a part in depleting the tissues of fluid. Recovery was apparently complete.

Saldun $^{14}$ describes a case of lipoid nephrosis in an infant. Oedema was marked and albumin in the urine reached $30 \mathrm{gm}$. per litre. The presence or absence of haematuria is not indicated. The Wassermann test was negative. Weight was lost during the course of the disease with diminution of oedema. The blood chemistry findings were: total proteins $7 \cdot 80 \mathrm{gm}$. per cent., albumin $3 \cdot 18 \mathrm{gm}$. per cent., globulin $4.62 \mathrm{gm}$. per cent., urea $14.0 \mathrm{mgm}$. per cent., serum calcium $4.9 \mathrm{mgm}$. per cent., serum phosphorus $5.0 \mathrm{mgm}$. per cent.; plasma Cl $230 \mathrm{mgm}$. per cent. Unfortunately 
the date of the blood chemistry findings with reference to the degree of oedema is not mentioned. On the development of bronchopneumonia, death occurred with generalized convulsions, seven weeks after the onset of the nephrosis.

Further references to blood chemistry are given in two cases commencing under eighteen months described as acute tubular nephritis (nephrosis) by Wolbach and Blackfan ${ }^{15}$. Insidious onset of anasarca was the main feature. Albuminuria was marked and haematuria absent. The total protein content of the plasma was $5.8 \mathrm{gm}$. per cent. and $3.2 \mathrm{gm}$. per cent., and non-protein nitrogen $55.0 \mathrm{mgm}$. per cent. and $44.0 \mathrm{mgm}$. per cent. respectively. At the post-mortem examination tubular degeneration was observed. The glomeruli were normal in one case and in the other there were slight changes which were attributed to septicaemia.

Mackay and Johnstone ${ }^{16}$, describe a case of lipoid nephrosis of seventeen years' duration starting at the age of one year and four months. Up to the time of death, which was due to streptococcal peritonitis, renal function tests were normal and cardiovascular changes were absent. Ehrich ${ }^{17}$, describing the pathology of the same case, found the kidneys large while microscopic examination revealed hyalinization of 50 per cent. of the glomeruli, the others being apparently normal.

Regarding chronic interstitial nephritis, Mitchell ${ }^{18}$, in an exhaustive review, says that comparatively few cases have been detected in infancy. Apparently the diagnosis is not easy at this age period. He considers the typical picture to be a high non-protein nitrogen with a tendency to low serum calcium and high serum phosphorus, with absence of oedema. Polyuria is present and albuminuria slight. Mitchell points out that the condition arises from kidney insufficiency due to (a) infective processes with or without deformity of the urinary tract, (b) congenital cystic disease of the kidney, or (c) congenital interstitial nephritis. None of the cases under discussion in this paper are of the chronic interstitial type.

Congenital Syphilis. - From a perusal of the literature the impression is gained that there is close causal relationship between syphilis and nephritis in infancy. Spence ${ }^{5}$ suggests that the presence of nephritic oedema in an infant should lead the observer to suspect syphilis.

Four of his five cases died and the fifth recovered on arsphenamine injection. Paterson $^{19}$ states that syphilitic nephritis is the commonest cause of oedema in infancy but other manifestations of syphilis are frequently present. Boyd's ${ }^{6}$ five cases, in which congenital syphilis was present, were clinically indistinguishable from acute mixed nephritis for although the spleen was palpable in all the patients the only other manifestations of syphilis were a rash, present in one case, and positive reactions to Wassermann's test. All these children died. Post mortem, however, well-marked evidence of congenital syphilis was present. Still ${ }^{7}$ quotes two cases with both clinical and pathological evidence of syphilis and nephritis. According to Pfaundler and Schlossmann ${ }^{20}$ post-mortem examination gives unmistakable evidence of the disease. Spence ${ }^{5}$ and Hutchison ${ }^{21}$ believe the skin and nasopharyngeal lesions found in congenital syphilis to be the indirect cause of the nephritis. Paterson and $\mathrm{Wyllie}^{8}$ report three cases with oedema and albuminuria in which the Wassermann reactions were positive. All died. Of the seventeen cases of nephritis in infancy reported by Levy ${ }^{10}$ six had congenital syphilis, in two of which he attributes the nephritis to mercurial treatment.

It is evident therefore from the literature that congenital syphilis may be a cause of nephritis in infancy, but conclusive proof has not been adduced that renal oedema, in the absence of manifest signs of lues, is due to syphilis.

\section{Clinical features of present series.}

Little can be said of the aetiology of nephritis in infancy from the data given in this paper. In one case infection of the upper respiratory tract 
and in two cases of the alimentary tract preceded the nephritis and conceivably may have been causal. Skin lesions were absent and there was no evidence of scarlet fever. The course of the disease was, in the absence of infection, afebrile and the infants were comparatively bright and did not present the features ' of a toxaemic illness. The urine contained large quantities of albumin and casts. Haematuria would seem to vary in amount with the duration of the illness. It was present in every case on admission. Cardiovascular changes were absent. Blood pressure records, made in only four instances, were of questionable value as the infants invariably cried during the determination. Oedema with ascites was marked in all the cases save one where it was confined to the face and legs.

There is one feature in this small series which appears to be more constant in its occurrence than in the nephritis of older children, namely, the obstinacy of the oedema. The dominating feature was the great reduction of serum proteins and the persistence of oedema and heavy albuminuria; in four cases haematuria completely disappeared and the clinical picture left was that of the nephrotic syndrome. This contrasts with the state of affairs in nephritis of older children in which the persistence of oedema is the exception rather than the rule. This apparently is the feature which gives the nephritis of infancy its grave prognosis, the tendency to infection in all oedematous subjects being well known. Eight of the ten cases showed infection of the respiratory or alimentary tract while in hospital, the ninth developed a double streptococcal orchitis and the tenth a cellulitis.

The oedema, it would appear, is the direct result of lowering of the serum proteins, especially the albumin fraction. Therefore as far as treatment is concerned, it is suggested that our energies should be directed towards producing a return to normal of the serum proteins.

One might also comment on the absence of uraemic signs. In one case generalized convulsions did occur and death followed after a period of coma. In view of the high non-protein nitrogen and phosphorus of the serum and the histological findings in this case of extensive interstitial changes the diagnosis might be one of true uraemia. In no case did the pseudo-uraemic or hypertensive type of convulsions, seen so frequently in acute nephritis in older children, occur.

Syphilis was apparently not a factor. In five cases the Wassermann reaction was negative and at post-mortem in other four no evidence of lues was found. In the tenth case the Wassermann reaction was not done and permission for a post-mortem examination was refused but there was no evidence of congenital syphilis either from the history or from the clinical examination. It would seem therefore that syphilis should not be diagnosed merely from the presence of oedematous nephritis in infancy in the absence of serological or definite post-mortem evidence. 
Biochemistry. - The most significant feature of the biochemical changes in this series is the reduction of serum oncotic pressure. Kylin ${ }^{22}$ using Pulfrich's refractometer found that till the second year of life serum proteins are lower than in adults. In this study Howe's method as modified by Hawk and Bergheim ${ }^{22 a}$ was used in estimating serum proteins. The following figures for normals obtained from a series of infants under two years of age with no apparent abnormality save mild rickets, are almost within the normal limit found in adults and are considerably higher than those obtained by Kylin, possibly because no case in this series was below three months old (see table 1).

TABLE 1.

SERUM PROTEIN aNd ONCOTIC PRESSURE: NORMAL CONTROLS.

\begin{tabular}{|c|c|c|c|c|c|c|c|}
\hline \multirow{2}{*}{\multicolumn{3}{|c|}{ Age. }} & $\begin{array}{l}\text { Number } \\
\text { of }\end{array}$ & $\begin{array}{l}\text { Total } \\
\text { proteins } \\
\text { gm. }\end{array}$ & $\begin{array}{l}\text { Albumin } \\
\text { gm. }\end{array}$ & $\begin{array}{l}\text { Globulin } \\
\text { gm. }\end{array}$ & \multirow{2}{*}{$\begin{array}{c}\text { Calculated } \\
\text { oncotic pressure } \\
\text { mm. Hg. }\end{array}$} \\
\hline & & & & \multicolumn{3}{|c|}{ Percentage figures. } & \\
\hline 3-6 months & 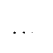 & $\ldots$ & 6 & $6 \cdot 51$ & $4 \cdot 67$ & $1 \cdot 84$ & $28 \cdot 2$ \\
\hline 6 months-1 year & $\ldots$ & $\ldots$ & 4 & $6 \cdot 76$ & $4 \cdot 76$ & $1 \cdot 99$ & $28 \cdot 9$ \\
\hline 1 year $-1 \frac{1}{2}$ years & $\cdots$ & $\cdots$ & 5 & $7 \cdot 53$ & $5 \cdot 26$ & $2 \cdot 27$ & $32 \cdot 1$ \\
\hline Under $1 \frac{1}{2}$ years & $\ldots$ & $\ldots$ & 15 & $6 \cdot 93$ & $4 \cdot 90$ & $2 \cdot 03$ & $29 \cdot 8$ \\
\hline Over $1 \frac{1}{2}$ years & $\ldots$ & $\ldots$ & 20 & $7 \cdot 42$ & $5 \cdot 02$ & $2 \cdot 39$ & $30 \cdot 9$ \\
\hline
\end{tabular}

In accordance with the view originated by Starling ${ }^{23}$ in 1891 one school of thought believes that oedema, other than that associated with acute nephritis or the development of cardiac failure, is due to reduction of the oncotic pressure of the serum. Whereas the normal is about $30 \mathrm{~mm}$. $\mathbf{H g}$. the critical level at which oedema tends to appear lies between 14 and 21 $\mathrm{mm}$. Hg. as calculated from Govaert's ${ }^{21}$ formula. Another factor in the development of oedema is the diminution of the capacity of the serum to hold salt $(\mathrm{NaCl})$ when the serum oncotic pressure falls. Although in acute nephritis the fall in oncotic pressure per se is in the majority of cases too slight in degree to be the cause of oedema yet Van Slyke and others ${ }^{25}$ have shown that 30 per cent. of cases of acute nephritis in their adult series had a reduction of serum oncotic pressure below the oedema level. In a recent publication it was shown that a similar tendency existed in 14 per cent. of cases of acute nephritis occurring in children between two and thirteen years of age. ${ }^{26}$ Perhaps the most salient feature of this investigation is that the calculated serum oncotic pressure was reduced below the oedema level in 
all the infants in whom the serum proteins were estimated (see table 2). In all the patients who recovered it was observed that a return to the normal level occurred as the oedema disappeared. In the other patient permission to obtain a sample of blood after recovery from nephritis was refused but the child was oedema-free and the urine contained no albumin.

TABLE 2.

TEN CASES OF NEPHRITIS IN INFANTS UNDER 18 MONTHS. INITIAL OBSERVATIONS ON ADMISSION.

\begin{tabular}{|c|c|c|c|c|c|c|c|c|c|}
\hline & \multirow{2}{*}{ Case. } & & \multirow{2}{*}{$\begin{array}{l}\text { Age in } \\
\text { Years. }\end{array}$} & \multirow{2}{*}{ Oedema. } & \multicolumn{3}{|c|}{ Gm. per $100 \mathrm{cc}$. of serum. } & \multirow{2}{*}{$\begin{array}{c}\text { Calculated } \\
\text { serum onc. } \\
\text { pressure } \\
\mathrm{mm} . \mathrm{Hg} .\end{array}$} & \multirow{2}{*}{$\begin{array}{l}\text { N.P.N. } \\
\text { mgm. } \\
\text { per cent. }\end{array}$} \\
\hline & & & & & $\begin{array}{c}\text { Total } \\
\text { pr otein. }\end{array}$ & $\begin{array}{l}\text { Alb- } \\
\text { umin. }\end{array}$ & $\begin{array}{l}\text { Glob- } \\
\text { ulin. }\end{array}$ & & \\
\hline 1 & J.Mc.D. & $\ldots$ & $\frac{9}{12}$ & $+\quad+$ & $3 \cdot 67$ & $1 \cdot 80$ & $1 \cdot 87$ & $12 \cdot 5$ & $28 \cdot 0$ \\
\hline 2 & I.G. & . & $1_{1}^{3} \frac{3}{2}$ & + & $3 \cdot 82$ & $2 \cdot 40$ & $1 \cdot 42$ & $15 \cdot 2$ & $29 \cdot 2$ \\
\hline 3 & A.H. & $\ldots$ & $\frac{7}{1} 2$ & $+\quad+$ & $4 \cdot 09$ & $1 \cdot 63$ & $2 \cdot 46$ & $12 \cdot 4$ & $27 \cdot 5$ \\
\hline 4 & s.c. & $\ldots$ & $1 \frac{4}{12}$ & $+\quad+$ & $4 \cdot 87$ & - & - & - & $24 \cdot 1$ \\
\hline $\mathbf{5}$ & C.G & $\ldots$ & $\frac{4}{12}$ & $+\quad+$ & $4 \cdot 83$ & $1 \cdot 60$ & $3 \cdot 23$ & $13 \cdot 3$ & $50 \cdot 0$ \\
\hline 6 & G.A. & $\cdots$ & $1_{Y^{2}}^{4}$ & $+\quad+$ & $4 \cdot 52$ & $2 \cdot 92$ & $1 \cdot 60$ & $18 \cdot 3$ & $28 \cdot 5$ \\
\hline 7 & J.N. & $\ldots$ & 1 & $+\quad+$ & $4 \cdot 23$ & $1 \cdot 96$ & $2 \cdot 27$ & 13.9 & $36 \cdot 3$ \\
\hline 8 & E.K. & $\ldots$ & $\frac{7}{12}$ & $+\quad+$ & - & - & - & - & - \\
\hline 9 & G.R. & $\ldots$ & $\frac{8}{12}$ & $+\quad+$ & $6 \cdot 78$ & $2 \cdot 66$ & $4 \cdot 12$ & $20 \cdot 4$ & $29 \cdot 1$ \\
\hline 10 & S.L. &. .1 & $1 \frac{1}{12}$ & $+\quad+$ & $4 \cdot 32$ & $2 \cdot 46$ & $1 \cdot 85$ & $16 \cdot 1$ & $65 \cdot 2$ \\
\hline 15 & normals & under & r $1 \frac{1}{2}$ & - & $6 \cdot 93$ & $4 \cdot 90$ & $2 \cdot 03$ & $29 \cdot 8$ & $<40 \cdot 0$ \\
\hline 20 & normals & over & $1 \frac{1}{2}$ & - & $7 \cdot 42$ & $5 \cdot 02$ & $2 \cdot 39$ & $30 \cdot 9$ & $<40 \cdot 0$ \\
\hline \multicolumn{5}{|c|}{ Level below which oedema may occur } & $5 \cdot 0$ & $2 \cdot 5$ & - & $14-21$ & - \\
\hline
\end{tabular}

In association with infection a high globulin was consistently observed. Leiter $^{27}$, and Darrow et alii $^{28}$, who induced low serum proteins in dogs by performing plasmapheresis, observed that globulin regenerated earlier and more rapidly than albumin during recovery when serum proteins rose and oedema disappeared. It is therefore possible that the disappearance of oedema following infection is due to the stimulus of infection causing serum proteins to regenerate, a rise in globulin preceding that of albumin.

Non-protein nitrogen was above normal in two cases only, case 5 in whom it reached a level of $50 \mathrm{mgm}$. per cent., and case $10,65 \cdot 2 \mathrm{mgm}$. per cent. It may be concluded that nitrogen retention is not generally present. In case 5 convulsions appeared a few hours before death and it is possible that uraemia was the cause. Serum phosphorus in that patient reached a. level of $7 \mathrm{mgm}$. per cent. but was not above $5.5 \mathrm{mgm}$. per cent. in the other cases in which it was estimated. Serum calcium was usually much reduced but in no instance was spasmophilia detected, suggesting that the 
reduction was at the expense of the protein-bound fraction which is held to be inert as regards its influence on neuro-muscular excitability (Salvesen and Linder $^{29}$ ).

Treatment. - Few suggestions of practical value can be put forward. One case recovered without treatment by drugs or diet. A high protein diet was given in one of our patients, case 1. For reasons already given it is doubtful if it was responsible for the return of the serum proteins to normal. At all events since there is seldom evidence of nitrogen retention a diet containing an amount of protein at least adequate for the age should be given and it should be salt free. In order to promote diuresis in acidproducing salt in the form of ammonium chloride was tried in two cases without producing any reduction in oedema. Peters et alii ${ }^{30}$ state that in adults where total protein is below $4 \mathrm{gm}$. per cent. the employment of diuretics is ineffective, and even if diuresis is obtained at higher levels of the serum proteins the tendency to oedema will remain till serum proteins rise. Therefore diuretics are merely palliative.

Pathology-Post-mortem examinations were made in four of the cases. All showed well-marked damage, of acute type, to both glomeruli and tubules. Case 5 in addition showed extensive proliferation of the interstitial tissue and round cell infiltration. These findings give no support to a diagnosis of pure lipoid nephrosis, the condition present being histologically a glomerulo-nephritis.

\section{Summary.}

1. Ten cases of acute nephritis in infants under eighteen months of age are reported. The clinical and biochemical findings are described. The disease was characterized by obstinate oedema and a reduction of serum proteins in every case. Seven of the cases were fatal, death being due in five or possibly six cases either to pneumonia or enteritis. In one case death was due to cellulitis. The other three cases made complete recoveries, in one without any special form of treatment. In one high protein diet and in another ammonuium chloride were used, but there was no evidence that recovery was due to these therapeutic measures.

2. There is no evidence that the nephritis was the result of a syphilitic infection.

3. The oedema is ascribed in every case to a fall in the serum protein with consequent reduction in the oncotic pressure. This was a constant finding and the condition differs in this respect from acute nephritis as seen in older children where fall in oncotic pressure below oedema level occurred in only fourteen per cent. Attempts at treatment should be directed towards causing a rise in the serum proteins as the cure is coincident with their return to normal. Spontaneous cure as in older children accounted for all the recoveries.

To Professor G. B. Fleming, Dr. Stanley Graham and Dr. Noah Morris I am indebted for many helpful suggestions, and to Dr. J. W. S. Blacklock and Dr. K. J. Guthrie for the notes on the post-mortem findings. 


\section{REFERENCES.}

1. Bruckman, F. S., I'Esopo, L. M., \& Peters, J. P., Jour. Clin. Invest., New York, 1930 , VIII, 577.

2. Epstein, A. A., Am. J. Med. Sc., Philad., 1922, CLXIII, 167.

3. Henoch, E., Lectures on Children's Diseases, II, London, 1889.

4. Holt, L. E., Diseases of Infancy and Childhood, London, 1897.

5. Spence, J. C., Diseases of Children, Garrod, A. E., et alii, London, 1929.

6. Boyd, G. L., Canad. Med. Assoc. J., Montreal, 1927, XVII, 894.

7. Still, G. F., Common Disorders and Diseases of Childhood, Oxford, 1927.

8. Paterson, D., \& Wyllie, W. G., Arch. Dis. Childh., London, 1926, I, 103.

9. Lyttle, J. D., \& Rosenberg, L. R., Am. J. Dis. Child., Chicago, 1929, XXXVIII, 1052.

10. Levy, S., Ztschr. f. Kinderh., Berlin, 1927, XLIII, 494.

11. Brown, A., Tisdall, F. F., \& Kelly, A. D., Selected Articles, Toronto.

12. Gray, J., Med. Res. Council, Spec. Report Series, No. 178, 1933.

13. Osman, A. A., Guy's Hospital Reports, London, 1926, LXXVI, 412.

14. Saldun, M., Arch. de. méd. d. enf., Paris, 1933, XXXVI, 41.

15. Wolbach, S. B., \& Blackfan, K. D., Am. J. Med. Sc., Philad., 1930, CLXXX, 453.

16. Mackay, E. M., \& Johnstone, C. J., Arch. Int. Med., Chicago, 1930, XLV, 734.

17. Ehrich, W., ibid., 749.

18. Mitchell, A. G., Am. J. Dis. Child., Chicago, 1930, XL, 101.

19. Paterson, D., Sick Children, London, 1930.

20. Pfaundler, M., \& Schlossmann, A., Diseases of Children, Philad., 1908.

21. Hutchison, R., Lectures on Diseases of Children, sixth edition, London, 1931.

22. Kylin, E., Acta Paed., Uppsala, 1932, XIV, 160.

22A. Hawk, P. B., \& Bergheim, O., Pract. Physiol. Chem., London, 1926.

23. Starling, E. H., J. Physiol., London, 1895-96, XIX, 312.

24. Govaerts, P., Compt. rend. Soc. de biol., Paris, 1925, XCIII, 441, ibid, 1926, XCV, 724.

25. Van Slyke, et alii, Medicine, Baltimore, 1930, IX, 257.

26. Rennie, J. B., Quart. J. Med., Oxford, 1933, II, n.s., 521.

27. Leiter, L., Medicine, Baltimore, 1931, X, 135.

28. Darrow, D. C., Hopper, E. B., \& Cary, M. K., Jour. Clin. Invest., New York, 1932, II, 683.

29. Salvesen, H. A., \& Linder, G. C., J. Biol. Chem., Baltimore, 1923-24, LVIII, 617.

30. Peters, J. P., et alii, J. Clin. Invest., New York, 1931, X, 941. 